\title{
A EMENDA CONSTITUCIONAL № 96, DE 6.6.2017 E O TEMA DA CRUELDADE CONTRA OS ANIMAIS NO CONTEXTO DA CULTURA E DA RELIGIÃO NA CONSTRUÇÃO JURISPRUDENCIAL DO SUPREMO TRIBUNAL FEDERAL
}

\begin{abstract}
Arnaldo Sampaio de Moraes Godoy
Livre Docente em Teoria Geral do Estado pela Faculdade de Direito da Universidade de São Paulo - USP. Pós-Doutor em Direito Constitucional pela Pontifícia Universidade Católica do Rio Grande do Sul - PUC-RS. Doutor e Mestre em Filosofia do Direito e do Estado pela Pontifícia Universidade Católica de São Paulo - PUC-SP. Professor titular do programa de Pós-Graduação do Centro Universitário de Brasília - Uniceub. E-mail: www. arnaldogodoy@ceub.br
\end{abstract}

\footnotetext{
Resumo: 0 artigo explora conflito entre o conteúdo de emenda constitucional e de decisão do Supremo Tribunal Federal. Com esse objetivo, indica e explica as linhas gerais de discussões que trataram de conflitos entre valores do patrimônio cultural brasileiro, inclusive em seus aspectos religiosos, em face de disposição constitucional referente à proibição da crueldade com os animais.
}

Palavras-chave: Emenda constitucional e decisão do Supremo Tribunal Federal. Conflitos entre normas e orientações da Constituição. Proteção do patrimônio cultural. Liberdade religiosa. A crueldade para com os animais. Vedações.

Sumário: Introdução e contornos do problema - 0 caso da farra do boi - 0 caso das rinhas de galos - 0 caso da vaquejada - 0 caso do sacrifício dos animais para fins religiosos - A Emenda Constitucional no 96, de 2017 - Considerações finais - Referências

\section{Introdução e contornos do problema}

A Emenda Constitucional ํo 96, de 6.6.2017, dispôs que não se consideram cruéis, para efeito de proibição constitucional, práticas desportivas que utilizem animais, desde que na forma de manifestações culturais, e sob as condições que a emenda enuncia. Um conjunto anterior de decisões do Supremo Tribunal Federal - STF fixou compreensão sobre o combate a qualquer forma de submissão dos animais à crueldade, ainda que no contexto de relações com o patrimônio cultural brasileiro. Esse conjunto de decisões de algum modo foi contornado pela emenda 
constitucional mencionada. A Emenda ํo 96, de 2017, não alcança religiões de matriz africana, nas quais há sacrifício de animais.

Essas decisões enfrentaram a questão dos maus tratos para com animais na vaquejada, ${ }^{1}$ na farra do boi, ${ }^{2}$ nas rinhas de galo ${ }^{3} \mathrm{e}$, mais recentemente, em cultos religiosos de matriz africana. ${ }^{4} \mathrm{O}$ Congresso Nacional alterou o texto constitucional que se discutia, ajustando-se à redação original da Constituição demandas de setores que se insurgiram contra mencionadas decisões, mais adiante estudadas.

Esses precedentes, com exceção do caso dos cultos religiosos, qualificam precedente, no sentido de que a ratio decidendi que as informou fixou teses jurídicas qualificadoras de decisões e de deferências para com elas (MARINONI, 2016), com acenos também para o Poder Legislativo. Do ponto de vista de uma teoria contemporânea das fontes do direito um conjunto de precedentes obriga (obviamente) muito mais do que mera orientação pretoriana (MANCUSO, 2014). Presencia-se um fortíssimo efeito vinculante das decisões do STF (LEAL, 2006) o que, em princípio, problematiza a mencionada emenda constitucional que alterou compreensão originária da matéria. Trata-se de uma emenda constitucional que desprezou uma decisão do STF.

O ponto de partida dessas discussões, sobre um prisma relativo ao fragmento constitucional que cuida do meio ambiente, consiste em obrigação do Poder Público no sentido de assegurar a efetividade ao meio ambiente ecologicamente equilibrado, no que se refere à vedação, na forma da lei, de práticas que submetam os animais à crueldade. ${ }^{5} \mathrm{Em}$ todas as hipóteses aqui discutidas, vaquejada, farra do boi, rinhas de galo e sacrifícios religiosos, ao que consta, essa submissão à crueldade poderia ser constatada. Ainda que, nesse último caso, a morte seria rápida e indolor, e realizada no contexto da liberdade de crença. Não se trata de meros conflitos resolviveis por diálogos interculturais (SARMENTO, 2016); o que se tem, na origem, é conflito que revela que direitos fundamentais não se confundem, necessariamente, com as normas que os asseguram (RUFINO, 2009). O núcleo da discussão centra-se no complexo tema dos direitos dos animais. ${ }^{6}$

STF. Ação Direta de Inconstitucionalidade no 4.983-CE. Rel. Min. Marco Aurélio, decisão de 2.6.2016.

STF. Recurso Extraordinário ํo 153.531-8-SC. Rel. p./ acórdão Min. Marco Aurélio, 2ª Turma, decisão de 3.6.1997.

3 STF. Ação Direta de Constitucionalidade no 1.856-RJ. Rel. Min. Celso de Mello, decisão de 26.5.2011.

STF. Recurso Extraordinário no 494.601-RS. Rel. p./ acórdão Min. Edson Fachin, decisão de 28.3.2019.

Constituição Federal, art. 225, §1ํㅡ, VII.

6 Por todos, Duarte e Gomes (2015). Desenvolvimentos recentes da legislação sobre animais em Portugal: uma breve crónica legislativa, Pedro Delgado Alves. Direito da União Europeia e estatuto jurídico dos animais: uma grande ilusão?, Maria Luísa Duarte. Direito dos animais: um ramo emergente?, Carla Amado Gomes. Direito Animal - Origens e desenvolvimentos sob uma perspectiva comparatista, Marisa Quaresma dos Reis. A controversa definição da natureza jurídica dos animais, Helena Telino Neves. Criação de animais de companhia, clubes de raça e protecção dos direitos dos animais... e dos donos, 
O assunto revela-se paradoxal, indicativo da compreensão de uma epistemologia que leve em conta a complexidade de problemas e eventuais soluções, porque há também norma de direito ambiental no pano de fundo (LEFF, 2002). O problema não se insere em temas mais óbvios, a exemplo de relações entre economia e ética, a propósito, por exemplo, do comércio (legal ou ilegal) de espécies silvestres (MILLER JR., 2007).

Do ponto de vista ético há um reclame moral para preservação e cuidado para com os animais envolvidos nas questões aqui tratadas (SINGER, 2002). Tem-se, assim, uma confluência entre economia e moral (SCRUTON, 2016), nos casos da vaquejada, da rinha e da farra do boi, o que justificou opiniões isoladas prolatadas nas várias decisões do STF. Os vários votos proferidos no STF revelam aspectos dessas nuances.

Deve-se levar em conta também determinação constitucional de que ao Estado incumbe garantir o pleno exercício dos direitos culturais e acesso às fontes da cultura nacional, bem como apoiar e incentivar a valorização e a difusão das manifestações culturais. ${ }^{7}$ A vaquejada, a farra do boi e a rinha são práticas que compõem o patrimônio cultural brasileiro, em sua dimensão imaterial, o que atrai a proteção constitucional de referência à identidade, à ação, à memória dos diferentes grupos formadores da sociedade brasileira, nos quais se incluem as várias formas de expressão, entre outros. ${ }^{8}$ Nesse sentido, há conflitos entre vários direitos difusos, de terceira dimensão, relativos ao meio ambiente e patrimônios culturais (ROTHENBURG, 2014).

No caso do sacrifício dos animais em relações a cultos de matriz africana, deve-se acrescentar o tema da liberdade de expressão cultural, no contexto da difusão de manifestações culturais populares africanas (SILVA apud LEITE; SARLET, 2009). Além do que, quanto ao sacrifício supostamente verificado em práticas de religiões de matriz africana, deve-se atentar também que há obrigação estatal para proteção de manifestações culturais afro-brasileiras. ${ }^{9}$ Transita-se no delicadíssimo campo das liberdades religiosas (WEINGARTNER NETO, 2007).

Este último caso diferencia-se substancialmente dos demais, porquanto é discutido no também amplo campo da liberdade religiosa, contido na inviolabilidade da liberdade de consciência e de crença, com a determinação para que seja assegurado o livre exercício dos cultos religiosos. ${ }^{10}$ A liberdade religiosa é

Mariana Melo Egídio. Dos crimes contra animais de companhia. Breves notas, Raul Farias. Perspetivas quanto à aplicação da nova legislação, Alexandra Reis Moreira.

Constituição Federal, art. 215.

Constituição Federal, art. 216.

9 Constituição Federal, art. 215, §1ㅇ․

10 Constituição Federal, art. 5ํ, VII. 
expressão fundamentadora dos direitos humanos (VERGÉS, 1997). Trata-se de um problema normativo fundamental (ADRAGÃO, 2002), cuja constatação de eficácia é justificativa, inclusive de proibição de retrocesso (SARLET, 2015).

Por força do conjunto das decisões do STF o Congresso Nacional discutiu e aprovou emenda constitucional dispondo que não se consideram cruéis as práticas desportivas que utilizem animais, desde que sejam manifestações culturais, nos termos da Constituição, registradas como bem de natureza imaterial integrante do patrimônio cultural brasileiro, devendo ser regulamentadas por lei específica que assegure o bem-estar dos animais envolvidos. ${ }^{11}$

Um dos argumentos que o presente artigo sustenta consiste na aparente impropriedade desse acréscimo no texto constitucional. Não se trata de retomada da discussão acadêmica referente à potencial inconstitucionalidade de excertos constitucionais (BACHOF, 1994), ou da fragilização de decisões majoritárias (Congresso Nacional) (WALDRON, 1999), em face de opções contramajoritárias (decisões de Cortes Constitucionais) (HIRSCHL, 2007). O assunto remete o estudioso à discussão clássica na doutrina constitucionalista norte-americana, referente ao papel do Judiciário (BICKEL, 1986).

O presente artigo tem por objetivo explorar essas tensões, que opõem direito ambiental (na sua expressão de proteção aos animais), direito à cultura e liberdade de expressão religiosa, a partir das discussões que se desdobraram no STF. Do ponto de vista metodológico, cuida-se de uma pesquisa documental (centrada em decisões do STF e demais documentos), de natureza explicativa, com a pretensão de sintetizar o atual estado da discussão.

Ao longo do texto são recorrentemente citados e parafraseados votos prolatados e argumentos sustentados por ministros do STF. Evitando-se citações textuais procura-se, na medida do possível, reproduzir-se o conteúdo decisório, tal como expresso no Plenário ou nos votos escritos. Trata-se de uma pesquisa de jurisprudência, cujo resultado é contraposto à emenda constitucional aprovada pelo Congresso Nacional. A matéria, do ponto de vista de análise jurisprudencial, vem provocando intervenções recorrentes, de natureza interpretativa. ${ }^{12}$

Com tais propósitos, o artigo cuida, separadamente, de decisões que são identificadas como paradigmas no assunto, descrevendo-as. 0 acórdão referente

11 Constituição Federal, art. 225, §7 ำ, nos termos da Emenda Constitucional nำ 96, de 2017.

12 No tema, consultar, por todos, Gomes, Dickstein, Giordano e Gonçalves (2020). No Supremo Tribunal Federal: Fabrício Meira, Anotação ao acórdão do Supremo Tribunal Federal de 28 de Março de 2019, rext (RE) proc. no 494.601. Sacrifício de animais em rituais religiosos; vaquejada. Rafaela Caobelli Oliveira, Anotação ao acórdão do Supremo Tribunal Federal de 30 de abril de 2014, proc. № 769878. Maus tratos contra animais. No Superior Tribunal de Justiça, Monique Mosca Gonçalves, Anotação ao acórdão do Superior Tribunal de Justiça, de 21.3.2019, REsp nº 1.797.195/SP. Animal; animais de companhia; senciência. 
à farra do boi é de 1997, o da rinha de galos é de 2011, o da vaquejada é de 2016 e o do sacrifício de animais para fins religiosos é mais recente, de 2019. A Emenda Constitucional no 96 é de 2017. Um sumário de considerações finais fecha o artigo.

\section{0 caso da farra do boi}

Tratava-se de recurso extraordinário com origem em ação civil pública na qual os requerentes almejavam obrigar o estado de Santa Catarina a proibir a festa da farra do boi. Pretendia-se constranger o requerido - o Poder Público em Santa Catarina - a cumprir obrigação de fazer, que consistia em medidas efetivas para que se obstaculizasse mencionada festa. Os interessados instruíram a inicial com documentos que comprovavam a crueldade, ainda que notórios os fatos discutidos. Buscava-se decisão judicial com vistas a proibir que municípios, distritos, subdistritos e outras localidades da faixa litorânea catarinense consentissem na realização do folguedo da farra do boi.

Contestou-se com o argumento (também notório) de que a festa consistia em manifestação histórica comum em parcela significativa da sociedade catarinense. Os advogados do estado de Santa Catariana argumentavam que não havia excessos, e que as autoridades daquela unidade federada cuidavam para que a crueldade não fosse a regra. Invocou-se que havia presença marcante das polícias civil e militar, que disciplinavam a festa, o que resultava no fato de que não se poderia constatar que havia o alegado mau trato para com os animais. Não se poderia confundir a festa tradicional, de origem açoriana (onde também denominada tourada à corda ou boi na vara), com alguma forma de violência que tratasse cruelmente os animais.

Documentos da Associação Catarinense de Proteção aos Animais e do Instituto Histórico e Geográfico do Estado de Santa Catarina propiciaram informações relativas a aspectos históricos, sociológicos e etnográficos relativos ao assunto, e que deveriam ser levados em conta. O Ministério Público local acompanhou a tese dos requerentes, protestando pela procedência da ação.

A decisão originária entendeu que o interessado era carecedor de ação, sob o argumento de que o pedido se mostrava juridicamente impossível. Não houve condenação em honorários, porquanto reconheceu-se que a postulação continha conteúdo também moral. Os requerentes apelaram da decisão. Reformouse a sentença originária, no entanto, atacando-se o mérito e decretando-se a improcedência do pedido. 
Quando a matéria chegou ao STF, em forma de recurso extraordinário, o representante do Ministério Público opinou pelo não conhecimento do apelo, forte na Súmula no 279 do STF, que veda o mero reexame de provas. Nesse entender, ao STF caberia decidir se a farra do boi seria de fato uma festa cruel e violenta, bem como se teria havido omissão do poder estatal, no sentido de não permitir que os animais fossem tratados com crueldade.

O relator, Francisco Rezek, decidiu pelo conhecimento e provimento do recurso, julgando pela procedência da ação civil pública, acatando e sufragando os termos nos quais a demanda fora proposta. 0 relator fez menção a duas tentações que poderiam rondar o magistrado em casos como o que julgava. Invocava, primeiramente, uma consideração metajurídica relativa a prioridades que deveriam ser levadas em conta. Isto é, lembrava que poderia haver questionamento no sentido de se indagar os porquês da preocupação com animais em um país no qual as desigualdades sociais são indiscutivelmente pungentes.

Rechaçou tal argumento sustentando que a indiferença para com os animais é de certa forma um meio caminho para com a indiferença para com os seres humanos. 0 pedido não poderia ser ridicularizado ou amesquinhado, sob o frágil pretexto de que o sofrimento humano não mereceria a mesma atenção merecida pela agonia dos animais.

Quanto ao tema da manifestação cultural, lembrou que a ação era dirigida contra o Poder Público, e que o objetivo consistia em se determinar que se cumprisse a Constituição. Consignou que a farra do boi, no entanto, era cronicamente violenta, de modo que não se tratava de manifestação episódica, com abusos tópicos que a pontilhavam. Desarmou a tese do Ministério Público pontuando que os fatos eram tristemente notórios e que, deste modo, não dependiam de prova.

O Ministro Rezek não sufragou a compreensão de que a farra do boi se trataria de uma manifestação cultural na qual haveria abusos avulsos. Definiu tratar-se de exercício abertamente violento, no qual se constata a crueldade para com os animais. A ação civil pública, assim, mostrava-se idônea, pretendia fim legítimo e contava com indiscutível proteção legal.

Maurício Corrêa sustentou que a discussão encetava um problema de fato (quaestio facti) e não de direito (quaestio iuris), pelo que deveria se prestigiar o direito à manifestação cultural, por parte dos adeptos da farra do boi. Não conheceu do recurso. Basicamente, indagou como tolher a farra do boi se a Constituição determinava a proteção às manifestações das culturas populares. Não admitia a proibição da festa, entendendo que o folguedo seria componente de um patrimônio cultural definido como brasileiro.

Com base em autores que estudaram a cultura catarinense, Maurício Corrêa definiu a farra do boi como uma tradição cultural regionalizada. A intervenção estatal, observou, somente seria necessária (e possível) nas hipóteses de 
excesso, quando o poder de polícia deveria se manifestar, com vistas a atender ao dispositivo constitucional que veda a crueldade para com os animais. Nesse sentido, não haveria antinomia entre dois comandos constitucionais. Entendeu que o problema era questão de polícia, e não de recurso extraordinário.

Insistiu que a farra do boi se caracteriza como inegável costume cultural, em forma de legítima manifestação popular, típica de habitantes do litoral de Santa Catarina. Defendia a repressão aos excessos o que, a seu ver, consistiria em uma outra histórica, não colocada empiricamente nos autos.

Em seguida, proferiu voto o então presidente do STF, Néri da Silveira. Realçou que o art. 215 (proteção cultural) da Constituição Federal deveria ser compreendido à luz do art. 3o, no sentido de que a cultura é elemento intrínseco à promoção da dignidade da pessoa humana. Por outro lado, levou em conta preceito constitucional (art. 225, VII) que veda a prática de atos que submetam animais à crueldade, decorrendo do dever do Estado de conter essas manifestações, ainda que inegavelmente culturais. O acórdão do Tribunal de Santa Catarina não levava em conta o conteúdo da proibição da crueldade para com os animais, o que, entendeu, justificaria a reforma da decisão e a ordem para que o inc. VII do art. 225 da Constituição vinculasse o Estado de Santa Catarina, quanto à farra do boi.

Marco Aurélio também acompanhou o relator, conhecendo e provendo o recurso. Recordou que a farra do boi é costume que fora trazido dos Açores para o Brasil. Sustentou que a manifestação cultural deveria ser estimulada. Entretanto, não se pode incentivar qualquer prática cruel para com os animais. Não haveria, no seu entender, poder de polícia capaz de controlar "uma turba ensandecida que vai atrás do animal para procedimentos que estarrecem”.

Rejeitou posição intermediária, que colmatasse o comando constitucional de apoio às manifestações culturais e a ordem, também constitucional, para que o poder público velasse pela não crueldade para com os animais. Julgou que não se tratava de uma manifestação cultural justificadora do agasalho da Constituição; afirmou que a farra do boi era prática que envolvia crueldade ímpar, na qual participavam pessoas envolvidas por paixões condenáveis.

O último integrante daquele colegiado parcial (turma), Nelson Jobim, não participou da sessão. Assentou-se, conclusivamente, que o Estado de Santa Catarina deveria velar para que a festa da farra do boi não resultasse em crueldade para com os animais. ${ }^{13}$

13 Ementou-se, da forma que segue: “COSTUME - MANIFESTAÇÃO CULTURAL - ESTÍMULO - RAZOABILIDADE - PRESERVAÇÃO DA FAUNA E DA FLORA - ANIMAIS - CRUELDADE. A obrigação de o Estado garantir a todos o pleno exercício de direitos culturais, incentivando a valorização e a difusão das manifestações, não prescinde da observância da norma do inciso VII do artigo 225 da Constituição Federal, no que veda prática que acabe por submeter os animais à crueldade. Procedimento discrepante da norma constitucional denominado "farra do boi'". 


\section{0 caso das rinhas de galos}

$\mathrm{Na}$ origem, ação direta de inconstitucionalidade proposta pelo procuradorgeral da República contra lei do Estado do Rio de Janeiro que legitimava a realização de competições entre aves definidas como não pertencentes à fauna silvestre. Tratava-se da Lei Estadual № 2.895, de 20.3.1998, cuja aplicação resultaria na permissão prática para a realização da conhecida briga (rinha) de galos.

Minudente, a lei questionada autorizava a criação e a realização de exposições e competições entre aves das raças combatentes, em todo o território do estado do Rio de Janeiro (art. $1^{\circ}$ ). As competições (denominadas de atividades esportivas do galismo) poderiam ser realizadas em centros esportivos denominados de rinhadeiros (art. $2^{\circ}$ ). Regulamentos poderiam ser elaborados pela Federação Esportiva e de Preservação do Galo Combatente do Estado do Rio de Janeiro (art. 3o). Os locais destinados às competições deveriam ser vistoriados anualmente, como medida protetiva à segurança dos sócios frequentadores (art. 5o). Um médico veterinário (ou um assistente capacitado) deveria atestar, antes das competições, o estado de saúde das aves que participariam das contendas (art. 6ํ). As rinhas não poderiam ser realizadas em locais próximos a igrejas, escolas ou hospitais (art. 8o). Proibiu-se a presença de menores de 18 anos nas competições, exceto quando acompanhados por pais ou responsáveis diretos (art. 9o).

O Ministério Público Federal argumentou que a lei fluminense que regulamentava a rinha contrariava o comando constitucional que determina que o poder público tome medidas que evitem que se pratique crueldade para com os animais. A Assembleia Legislativa do Rio de Janeiro e o governador dessa unidade federada insistiram, entre outros, que a lei questionada não agredia o meio ambiente, não deixaria a fauna desprotegida, não prejudicaria a função ecológica, não provocaria a extinção de animais e que não submeteria os animais (galos) à crueldade. Analogicamente, lembraram que não há proibição à corrida de cavalos.

o Plenário do STF deferiu medida liminar, suspendendo, até o final do julgamento da ação direta, a execução e a aplicabilidade da lei questionada. O Advogado-Geral da União, cuja missão constitucional consiste em defender todas as leis impugnadas, porque curador da lei, opinou, de tal maneira, pela improcedência do pedido.

O relator, Celso de Mello, julgou procedente a ação direta e declarou a inconstitucionalidade da lei do estado do Rio de Janeiro que autoriza a rinha. Afastou de plano o argumento de que a discussão dependia de reexame de provas, consistente na necessidade de se comprovar (efetivamente) se a briga de galos resultava em crueldade para com os animais. Justificou que é notório 
("todos sabemos") que os galos sofrem ferimentos quando em combate. A lei fluminense que permitia a briga de galos mostrava-se incompatível com cláusula constitucional protetora, que veda crueldade com animais.

A legislação questionada operacionalizaria prática que o ordenamento jurídico brasileiro reputa como ilícita e criminosa. Celso de Mello invocou, nesse aspecto, a Lei o 9.605, de 12.2.1998, que dispõe sobre as sanções penais e administrativas derivadas de condutas e atividade lesivas ao meio ambiente. Nos termos do art. 32 de referida norma de proteção ambiental, o abuso, os maus-tratos, o ferimento e a mutilação de animais silvestres, domésticos ou domesticados, nativos ou exóticos submetem o agente a penas de detenção e de multa.

Nos termos da decisão do relator, há o dever ético-jurídico de preservação da fauna (e da não incidência em práticas de crueldade contra animais) e a subsistência do gênero humano em meio ecologicamente equilibrado. A submissão de animais a formas de crueldade, prossegue, representaria impacto negativo na incolumidade do patrimônio ambiental dos seres humanos, em virtude de comportamentos predatórios e lesivos. Direitos de terceira geração (mencionados como de novíssima dimensão) materializariam direitos de titularidade coletiva, que justificariam o repúdio à lei fluminense que autorizaria as brigas de galos.

Em tema de briga de galos havia precedente do STF, que já se pronunciara pela inconstitucionalidade de lei semelhante do estado de Santa Catarina (Lei no 11.366 , de 2000). Essa lei autorizava e regulamentava a criação e a exposição de aves de raça e a realização das brigas de galo. ${ }^{14}$ Foi declara inconstitucional pelo STF. ${ }^{15}$

Com base em farta literatura especializada e em excertos de outras decisões, Celso de Mello evidenciou as várias crueldades que seriam praticadas com os galos no ambiente da rinha, a exemplo do aprisionamento em gaiola de espaço mínimo, da suspensão dos animais para que fortaleçam suas unhas na areia, dos exercícios para aumento de resistência, do sofrimento com esporas postiças de metal, em brigas que duram até 1 hora e 15 minutos.

Para o relator, identificar a briga de galos como atividade desportiva, prática cultural ou expressão folclórica, seria tentativa patética de se fraudar a aplicação de regra constitucional de proteção da fauna. Briga de galos, ou de cães, observou,

STF. ADI no 2.514-SC. Rel. Min. Eros Grau, j. 29.6.2005.

15 "EMENTA: AÇÃO DIRETA DE INCONSTITUCIONALIDADE. LEI N. 11.366/00 DO ESTADO DE SANTA CATARINA. ATO NORMATIVO QUE AUTORIZA E REGULAMENTA A CRIAÇÃO E A EXPOSIÇÃO DE AVES DE RAÇA E A REALIZAÇÃO DE 'BRIGAS DE GALO'. A sujeição da vida animal a experiências de crueldade não é compatível com a Constituição do Brasil. Precedentes da Corte. Pedido de declaração de inconstitucionalidade julgado procedente". 
são condutas delituosas e aviltantes. Não poderiam, de forma alguma, receber algum tipo de tolerância, por parte das autoridades públicas.

Dias Toffoli divergiu, em voto sucinto, julgando improcedente a ação, argumentando que a proteção da flora e da fauna é matéria constitucionalmente reservada à lei (art. 225, VII), pelo que a questão deveria ser remetida à legislação criminal-ambiental.

Ayres Britto impugnou a decisão de Dias Toffoli, no sentido de que a proteção à crueldade não se daria somente a partir da edição de uma lei. Não se trataria de uma norma constitucional de eficácia limitada ou de eficácia complementar. Lembrou que se tinha como parâmetro uma Constituição promulgada explicitamente sobre a proteção de Deus, o que repele, por absoluto, a autoexecução de animais. Acrescentou que nas brigas de galo tem-se uma forma de tortura, que a Constituição veda peremptoriamente (art. 5으, III). Há, na briga de galo, segundo Ayres Britto, derramamento de sangue, mutilação física, exaustão e morte. Acompanhou o relator e votou pela inconstitucionalidade da lei fluminense.

Luiz Fux seguiu essa tendência e sublinhou que a Constituição detém normatividade suficiente para proibir as brigas de galos. Marco Aurélio apontou para o precedente da discussão referente à farra do boi, acrescentando que a lei fluminense continha vício também do ponto de vista formal, dado que entendia que a matéria deveria ser regulamentada por lei federal. Dias Toffoli retificou seu voto e acompanhou Marco Aurélio, no sentido de que lei federal deveria regular a matéria. Gilmar Mendes também acompanhou o relator. Da mesma forma, Cármen Lúcia. Por fim, Ricardo Lewandowski enfatizou a qualidade do voto condutor lembrando que se constata movimento mundial no sentido de se evitar a crueldade para com os animais. Com esse propósito fez referência à proibição das touradas em Barcelona. O STF, assim, decidiu pela inconstitucionalidade de lei fluminense que permitia as brigas de galos. ${ }^{16}$

16 “EMENTA: AÇÃO DIRETA DE INCONSTITUCIONALIDADE - BRIGA DE GALOS (LEI FLUMINENSE № 2.895/98) - LEGISLAÇÃO ESTADUAL QUE, PERTINENTE A EXPOSIÇÕES E A COMPETIÇÕES ENTRE AVES DAS RAÇAS COMBATENTES, FAVORECE ESSA PRÁTICA CRIMINOSA - DIPLOMA LEGISLATIVO QUE ESTIMULA O COMETIMENTO DE ATOS DE CRUELDADE CONTRA GALOS DE BRIGA - CRIME AMBIENTAL (LEI № 9.605/98, ART. 32) - MEIO AMBIENTE - DIREITO À PRESERVAÇÃO DE SUA INTEGRIDADE (CF, ART. 225) - PRERROGATIVA QUALIFICADA POR SEU CARÁTER DE METAINDIVIDUALIDADE - DIREITO DE TERCEIRA GERAÇÃO (OU DE NOVÍSSIMA DIMENSÃO) QUE CONSAGRA O POSTULADO DA SOLIDARIEDADE PROTEÇÃO CONSTITUCIONAL DA FAUNA (CF, ART. 225, §1ํㅡ, VII) - DESCARACTERIZAÇÃO DA BRIGA DE GALO COMO MANIFESTAÇÃO CULTURAL - RECONHECIMENTO DA INCONSTITUCIONALIDADE DA LEI ESTADUAL IMPUGNADA - AÇÃO DIRETA PROCEDENTE. LEGISLAÇÃO ESTADUAL QUE AUTORIZA A REALIZAÇÃO DE EXPOSIÇÕES E COMPETIÇÕES ENTRE AVES DAS RAÇAS COMBATENTES - NORMA QUE INSTITUCIONALIZA A PRÁTICA DE CRUELDADE CONTRA A FAUNA - INCONSTITUCIONALIDADE. [...]”. 


\section{0 caso da vaquejada}

$\mathrm{Na}$ origem, ação direta de inconstitucionalidade proposta pelo procuradorgeral da República que contestou lei do estado do Ceará (Lei no 15.299, de 8.1.2013) que regulamentava a vaquejada como prática desportiva e cultural. A lei impugnada definia a vaquejada como "evento de natureza competitiva, no qual uma dupla de vaqueiro a cavalo persegue animal bovino, objetivando dominálo" (art. 2º́). Explicitou-se que "a competição deve ser realizada em espaço físico apropriado, com dimensões e formato que propiciem segurança aos vaqueiros,

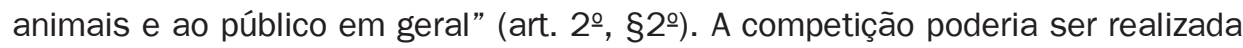
em formas amadora ou profissional (art. 3o). Consignou-se também que se 0 vaqueiro, injustificadamente, ferisse ou matasse o animal, de forma intencional, seria excluído da prova (art. 4ํㅗ요으.

Mais uma vez o STF enfrentava antinomia entre o direito ao meio ambiente (art. 225) e o direito às manifestações culturais, enquanto manifestações de pluralidade (art. 215). Quanto a aspectos mais práticos, contava-se com a informação de que a vaquejada resultava em empreendimento comercial muito lucrativo, movimentando cerca de $\mathrm{R} \$ 14$ milhões de reais por ano. Nos termos da peça inicial, verifica-se que os bois eram enclausurados, açoitados e instigados; lesões traumáticas e danos irreparáveis atingiriam também os cavalos.

Os requeridos insistiam na importância histórica da vaquejada. A imposição de sanção aos maus tratos qualificaria medida suficiente para que se evitasse a crueldade para com os animais envolvidos nas pelejas. Contavam com fortíssimo argumento de ordem legislativa. A Lei Federal $\mathrm{n}^{0}$ 10.220, de 11.4.2001, ${ }^{17}$ que instituía normas gerais relativas à atividade de peão de rodeio, equiparando-o ao atleta profissional, reconhecia a vaquejada como prática merecedora de proteção legal.

A vaquejada, na linha de defesa do estado do Ceará, qualificava-se como um direito cultural reconhecido pelo art. 215 da Constituição Federal. Incentivava o turismo, gerava empregos sazonais e protagonizava alta relevância na economia

“Art. 1ํㅡ Considera-se atleta profissional o peão de rodeio cuja atividade consiste na participação, mediante remuneração pactuada em contrato próprio, em provas de destreza no dorso de animais eqüinos ou bovinos, em torneios patrocinados por entidades públicas ou privadas. Parágrafo único. Entendem-se como provas de rodeios as montarias em bovinos e eqüinos, as vaquejadas e provas de laço, promovidas por entidades públicas ou privadas, além de outras atividades profissionais da modalidade organizadas pelos atletas e entidades dessa prática esportiva. Art. $2^{\circ}[\ldots] \S 1^{\circ}$ É obrigatória a contratação, pelas entidades promotoras, de seguro de vida e de acidentes em favor do peão de rodeio, compreendendo indenizações por morte ou invalidez permanente no valor mínimo de cem mil reais, devendo este valor ser atualizado a cada período de doze meses contados da publicação desta Lei, com base na Taxa Referencial de Juros - TR. [...] Art. 3o o contrato estipulará, conforme os usos e costumes de cada região, o início e o término normal da jornada de trabalho, que não poderá exceder a oito horas por dia [...]". 
local. E porque lei federal reconhecia a vaquejada como rodeio não poderia o STF, nesse caso, assentar inconstitucionalidade de norma federal por arrastamento.

A Advocacia-Geral da União, ainda que curadora da lei, protestou pela procedência do pedido. Reconheceu o valor cultural da prática, porém distinguiu que há exposição dos animais a maus-tratos e crueldade. O relator, Marco Aurélio, nesse pormenor, registrou que a AGU deixou de cumprir preceito constitucional porque não defendeu a lei questionada. ${ }^{18}$

0 relator decidiu pela inconstitucionalidade da lei cearense. Enfrentou a questão da ponderação de valores, dada a antinomia entre duas orientações constitucionais. Retomou decisão pretérita de sua autoria, no caso "Reserva Extrativista Verde para Sempre", ${ }^{19}$ quando, em face de conflito entre pretensão coletiva e pretensão individual, decidiu que o intérprete deveria optar por aquela primeira. A preponderância do interesse coletivo (no caso, a negativa de que se tenha crueldade com animais) faz com que um interesse particularizado (no caso, dos adeptos da vaquejada) seja desprestigiado.

Marco Aurélio fez referência à linha de precedentes que triunfava, e que se desenhava desde o caso da farra do boi, retomado no caso da briga de galos. A linha de precedentes apontava uma ótica adotada pelo STF, que em juízo de ponderação rechaçava a norma de proteção cultural, em favor da norma de proteção ambiental. Buscava padrão decisório que se justificava pelos laudos técnicos levados aos autos.

Havia comprovação empírica de que a vaquejada redundava em sofrimento, para os bois, assim como para os cavalos. Uma tortura prévia também precedia o espetáculo, mediante a aplicação de choques elétricos. Concluiu que a composição

18 “PROCESSO OBJETIVO - AÇÃO DIRETA DE INCONSTITUCIONALIDADE - ATUAÇÃO DO ADVOGADO-GERAL DA UNIÃO. Consoante dispõe a norma imperativa do §3으 do artigo 103 do Diploma Maior, incumbe ao Advogado-Geral da União a defesa do ato ou texto impugnado na ação direta de inconstitucionalidade, não Ihe cabendo emissão de simples parecer, a ponto de vir a concluir pela pecha de inconstitucionalidade".

19 "Ementa: MEIO AMBIENTE - RESERVA EXTRATIVISTA - CONFLITO DE INTERESSE - COLETIVO VERSUS INDIVIDUAL. Ante o estabelecido no artigo 225 da Constituição Federal, conflito entre os interesses individual e coletivo resolve-se a favor deste último. PROPRIEDADE - MITIGAÇÃO. O direito de propriedade não se revela absoluto. Está relativizado pela Carta da República - artigos 5으, incisos XXII, XXIII e XXIV, e 184. ATO ADMINISTRATIVO - PRESUNÇÃO. Os atos administrativos gozam da presunção de merecimento. RESERVA DE PROTEÇÃO AMBIENTAL - CRIAÇÃO - ALTERAÇÃO - SUPRESSÃO. A criação de reserva ambiental faz-se mediante ato administrativo, surgindo a lei como exigência formal para a alteração ou a supressão - artigo 225, inciso III, do Diploma Maior. RESERVA AMBIENTAL - CONSULTA PÚBLICA E ESTUDOS TÉCNICOS. O disposto no $\S 2^{\circ}$ do artigo 22 da Lei no 9.985/2000 objetiva identificar a localização, a dimensão e os limites da área da reserva ambiental. RESERVA EXTRATIVISTA - CONSELHO DELIBERATIVO GESTOR - OPORTUNIDADE. A implementação do conselho deliberativo gestor de reserva extrativista ocorre após a edição do decreto versando-a. RESERVA EXTRATIVISTA - REFORMA AGRÁRIA - INCOMPATIBILIDADE. Não coabitam o mesmo teto, sob o ângulo constitucional, reserva extrativista e reforma agrária. RESERVA EXTRATIVISTA - DESAPROPRIAÇÃO - ORÇAMENTO. A criação de reserva extrativista prescinde de previsão orçamentária visando satisfazer indenizações" (MS no 25.284/DF. Rel. Min. Marco Aurélio, j. 17.6.2010). 
dos interesses fundamentais envolvidos na discussão exigia que sobressaísse a proteção do meio ambiente.

Edson Fachin divergiu do relator, chegando à conclusão oposta. Votou pela improcedência do pedido. Do texto da petição inicial isolou passagem do representante do Ministério Público Federal que reconhecia que a vaquejada traduzia uma manifestação cultural. Rejeitou equipar a questão ao discutido nos casos da farra do boi e da briga de galos. Prestigiou uma realidade que identificava como procedente da população rural. A proibição da vaquejada atenderia à perspectiva cultural de uma sociedade urbana. E por firmar o convencimento de que a vaquejada se qualificaria como manifestação cultural, com apoio de disposição constitucional, entendeu que deveria prestigiar uma característica do modo de vida da população sertaneja.

Gilmar Mendes seguiu a linha de Edson Fachin. Argumentou que a recusa à fruição de direitos culturais poderia tornar a vida muito "aborrida [sic]". Lembrou o direito alemão (art. 2o da Lei Fundamental) no sentido de que a liberdade é também um aspecto do desenvolvimento da personalidade, que também se vincula a direitos de caráter cultural. Fez referência à festa do peão, que ocorre em Barretos, no estado de São Paulo. Insistiu na Constituição como cultura, tema de Peter Haberle, a quem se referiu como "mestre".

Do ponto de vista mais prático sustentou que a declaração de inconstitucionalidade da vaquejada poderia prejudicar a vida de milhares de pessoas, retirando de várias comunidades rurais oportunidades de lazer. Nos termos do voto, o propósito da vaquejada não consiste em se matar o boi. Por isso, negou que haveria semelhanças do caso que se julgava com a farra do boi e com a rinha de galos.

Apresentou voto no qual fez referência ao direito constitucional alemão, com especial ênfase a um caso no qual se decidiu que restrições às cavalgadas violavam o livre desenvolvimento da personalidade. Acrescentou vários argumentos de ordem econômica, lembrando que há mais de 10.000 parques de vaquejadas, com geração de cerca de 200.000 empregos, diretos ou indiretos.

A propósito da festa do peão de Barretos, Ricardo Lewandowski usou da palavra e esclareceu que várias medidas são tomadas no estado de São Paulo para se evitar o sofrimento de animais. Proíbe-se o uso de esporas com rosetas cortantes, bem como de tiras de couro que são apertadas sobre os rins dos animais, além de choques elétricos e uso de outros instrumentos contundentes.

Em Plenário a discussão alcançou um momento curioso. Luiz Fux fez uma analogia entre a vaquejada e os esportes de confronto, que são regulados, e nos quais há autorização do titular do bem jurídico ofendido. Roberto Barroso observou que tinha alguma dificuldade em compreender a analogia, porquanto não 
se poderia supor que o semovente pudesse consentir com o esporte. Para Luiz Fux o Estado seria o representante do animal, evitando que fosse sacrificado.

Em voto-vista, Roberto Barroso julgou procedente a ação direta declarando inconstitucional lei estadual que regulamenta a vaquejada como prática esportiva e cultural. Entendeu que a torção brusca da cauda do animal em alta velocidade e sua derrubada seria inerentemente cruel e lesiva para o animal. Reportou-se ao princípio da precaução, deflagrado desde a potencialidade da lesão ao animal.

O voto de Roberto Barroso, com referência também em Luís da Câmara Cascudo, folclorista potiguar, explica com extensão a prática da vaquejada, no contexto da pecuária nordestina dos séculos XVII e XVIII. Historiou o debate em torno de uma ética animal, com estação nos pensadores canônicos na tradição filosófica ocidental, a exemplo de Aristóteles, São Tomás, Descartes e Kant.

Noticiou uma ideologia vinculada a movimento de proteção de direitos dos animais, alcançando uma ideia de Estado Constitucional Ecológico. Entre os vários aspectos cruéis que ocorrem na vaquejada, mencionou a "maçaroca", que resulta na quebra da cauda do animal. Não há como se regulamentar a vaquejada, é conclusão que se constata nesse extenso voto. Por fim, consignou que em ambiente de novos valores e de novas percepções o STF cumpre opções éticas dos constituintes, no sentido de proteger animais contra práticas de submissão a crueldade.

Teori Zavascki acompanhou a divergência, não constando inconstitucionalidade na lei questionada. Porque percebia que poderia haver vaquejadas cruéis e vaquejadas não cruéis, entendia que a lei possibilitava um combate àquelas primeiras. Rosa Weber acompanhou o relator enfatizando que prestigiava uma matriz biocêntrica. A Constituição, nos termos de seu pronunciamento, também confere um valor intrínseco a formas de vida não humanas, a exemplo de seres sencientes.

Luiz Fux acompanhou a divergência. Descreveu o modo como se abate um boi para consumo, evidenciando a crueldade para com o animal. Em contraposição lembrou que a Constituição também consagra a alimentação como um direito social e inalienável. Contestou, também, alguma universalidade na questão, lembrando que, na Índia, a vaca é sagrada, enquanto no Brasil é abatida para consumo.

Celso de Mello apresentou extenso voto, centrado no direito à integridade do meio ambiente, cuja titularidade é da coletividade social. Retomou a linha de raciocínio no voto que elaborou por ocasião da discussão em torno da briga de galos, e considerou inconstitucional a prática da vaquejada.

Dias Toffoli fez referência ao livro de Gênesis e ao que denominou "o grande pacto civilizatório". Mencionou o sacrifício de Isaac, por parte de seu pai, Abraão, que não se consumou. Também acompanhou a divergência, julgando improcedente 
a ação, entre outros, porque não percebia provas cabais de que na vaquejada os animais seriam vítimas de abuso, de crueldade e de maus tratos, de modo sistemático.

Ricardo Lewandowski acompanhou o relator. Sugeriu também uma interpretação biocêntrica do art. 225 da Constituição Federal, ao que reputou como uma perspectiva antropocêntrica, que levaria em conta os animais como coisas. Cármen Lúcia também acompanhou o relator, julgando procedente o pedido. Entendia que os folguedos em discussão se consubstanciavam em manifestações extremamente agressivas contra os animais. O STF decidiu, assim, por maioria, pela inconstitucionalidade da lei da vaquejada. ${ }^{20}$

\section{O caso do sacrificio dos animais para fins religiosos}

$\mathrm{Na}$ origem, a discussão em torno de uma lei do estado do Rio Grande do Sul. Tratava-se da Lei Estadual no 12.131, de 22.6.2004, que acrescentava um parágrafo único ao art. 2o do Código Estadual de Proteção aos Animais daquela unidade federada. Excetuava-se da proibição de crueldade para com os animais o livre exercício dos cultos e liturgias de matriz africana. A lei, desse modo, dispunha que não se enquadrava no conceito de maus tratos para com animais os sacrifícios praticados em religiões de matriz africana.

O STF sustentou a constitucionalidade da lei questionada, produzindo tese com a redação que segue: “É constitucional a lei de proteção animal que, a fim de resguardar a liberdade religiosa, permite o sacrifício ritual de animais em cultos de religiões de matriz africana".

A Procuradoria Federal dos Direitos do Cidadão, por intermédio de grupo de trabalho (Enfrentamento e Prevenção ao Racismo) confeccionou e divulgou material de apoio às discussões que se travaram no STF. ${ }^{21}$ Nesse estudo substancial

20 "VAQUEJADA - MANIFESTAÇÃO CULTURAL - ANIMAIS - CRUELDADE MANIFESTA - PRESERVAÇÃO DA FAUNA E DA FLORA - INCONSTITUCIONALIDADE. A obrigação de o Estado garantir a todos o pleno exercício de direitos culturais, incentivando a valorização e a difusão das manifestações, não prescinde da observância do disposto no inciso VII do artigo 225 da Carta Federal, o qual veda prática que acabe por submeter os animais à crueldade. Discrepa da norma constitucional a denominada vaquejada".

21 O material consta da Nota Técnica no 5-2018-PFDC-MPF, sobre o livre exercício das religiões de matriz africana e a proibição de sacrifício ritualístico de animais (inconstitucionalidade), de autoria da Procuradora Federal dos Direitos do Cidadão Deborah Duprat, e do Procurador Regional da República Dr. Walter Claudius Rothenburg. Disponibilizou-se também o relatório "Estado laico e combate à violência religiosa", de autoria do Procurador da República Jaime Mitropoulos. Divulgou-se também parecer jurídico sobre abate religioso, de autoria dos advogados Hélio Silva Jr., Antônio Basílio Filho, Jáder Freire de Macedo Jr., Demetrius Barreto Teixeira e Júlio Romário da Silva. Desse documento foram colhidas várias informações apresentadas no presente artigo. 
avaliam-se vários aspectos da demanda, a exemplo da ponderação de valores, dos precedentes no STF, da situação fática do Rio Grande do Sul (que ensejou o recurso extraordinário), bem como o estado da arte do problema no estado de São Paulo. Ao que consta, questão muito parecida ocorrera com lei do município de Cotia, cuja lei proibiu, de modo generalizado, a utilização, mutilação e sacrifício de animais em rituais religiosos ou de qualquer natureza. O Tribunal de Justiça de São Paulo teria julgado inconstitucional essa lei municipal. Os legisladores daquele município paulista deixaram de levar em conta exceção que atendesse ao livre exercício dos cultos e liturgias de matriz africana.

O documento disponibilizado pelo Ministério Público Federal enfatizou aspectos referentes ao livre exercício da crença religiosa. Fez referência ao direito comparado, entre outros, em relação à decisão da Suprema Corte dos Estados Unidos que definiu pela inconstitucionalidade de norma municipal que proibiu o sacrifício de animais em rituais religiosos. Trata-se do caso Church of Lukumi Babalu Aye, Inc. v. City of Hialeah. ${ }^{22}$

O documento do Ministério Público levou em conta também a Declaração Universal dos Direitos Humanos (art. 18), o Pacto Internacional sobre Direitos Civis e Políticos (art. 18), a Declaração da ONU sobre a eliminação de todas as formas de intolerância e discriminação fundadas na religião ou convicções (arts. 1 e 6), a Declaração da ONU sobre os direitos das pessoas pertencentes a minorias nacionais ou étnicas, religiosas e linguísticas (art. 4), bem como a declaração da Unesco, relativa aos princípios sobre a tolerância (art. $1^{\circ}$ ).

Constata-se que o problema da constitucionalidade da lei gaúcha que excepcionava do conceito de tratamento cruel os sacrifícios praticados em ambiente de religiões de matriz africana transcende às discussões até então travadas no STF. Aspectos de liberdade de consciência religiosa e de racismo (em virtude da hostilidade para com religiões de matriz africana) alteravam os parâmetros do que fora até agora discutido pelo STF. A questão não se limitava ao tema da crueldade para com os animais, em oposição a direitos de manifestação cultural, ainda que inegavelmente - a religião seja uma expressão da cultura humana.

Admitiu-se o sacrifício de animais em cultos religiosos de matriz africana, excepcionando-se regra geral de proibição de maus tratos para com animais. Marco Aurélio proferiu voto dando interpretação conforme a Constituição em relação à lei estadual contestada. Ajustou o conteúdo da norma impugnada às linhas gerais das prescrições constitucionais. Condicionou o abate ao consumo da carne. Edson Fachin reconheceu que o sacrifício de animais é intrínseco aos cultos de matriz africana. Proibi-los, argumentou, reforçaria o estigma e o preconceito. Ricardo

22 US Supreme Court, 508 U.S. 520 (1993). 
Lewandowski não detectou incompatibilidade entre a lei gaúcha contestada e a Constituição.

Alexandre de Moraes também votou por interpretação da regra questionada de modo conforme à Constituição. Optou por definir a constitucionalidade de ritos religiosos nos quais há sacrifícios de animais, retirando desse conjunto a prática de maus tratos. Discordou de Marco Aurélio, porque não vinculou o sacrifício do animal ao consumo da carne. Roberto Barroso também concordou com a exceção legal e observou que é comum nos cultos de matriz africana o sacrifício indolor. Não haveria, nos termos de seu pronunciamento, o sacrifício como mero entretenimento: trata-se do exercício de um direito fundamental que a todos deve ser garantido, e que consiste na liberdade religiosa.

Rosa Weber acrescentou ao argumento o tema das cotas raciais, no sentido de que a discussão também alcança problemas de preconceito. Por isso, necessário que se garanta aos adeptos das religiões de matriz africana o livre exercício de suas práticas tradicionais. Seu voto foi no sentido de que o reconhecimento da constitucionalidade da lei gaúcha contestada representaria um enfrentamento à intolerância, ao preconceito e ao estigma. Luiz Fux acrescentou que a decisão do STF contribuiria para enfrentar onda de preconceito e violência contra as religiões afro, cujos centros de culto sofrem constantes atentados. Cármen Lúcia seguiu na mesma linha, também adotada por Dias Toffoli.

\section{A Emenda Constitucional no 96, de 2017}

Os julgados firmados pelo STF, especialmente nos casos da farra do boi, da briga de galos e da vaquejada, enquadram-se em uma concepção pragmática que justifique a adoção de um sistema de precedentes. Há valores e comportamentos que se formulam no contexto do decidido, e que justificam a busca da unidade e desenvolvimento do direito, bem como uma aplicação clara e geral, que promova a igualdade, o fortalecimento institucional, a previsibilidade e também a racionalidade econômica (MARINONI, 2014, p. 101 e ss.).

Essa orientação jurisprudencial parece contrariada por emenda constitucional que alterou o conteúdo do decidido pelo STF. A Emenda Constitucional no 96, de 2017, resultou da PEC n 50/2016, de autoria do Senador Otto Alencar do PSD-BA. Na justificação que se juntou ao projeto, quando de sua tramitação, observou-se que o STF fora instado a se manifestar sobre o conflito que decorria entre o alcance do art. 215, caput e $\S 1^{\circ}{ }^{\circ}$ do texto constitucional (proteção de manifestações culturais populares) em face do art. 225, §1ํㅡ, VII (proteção dos animais contra a crueldade). 
Consignou-se que o STF julgou pela procedência do pedido, o que suscitou polêmica entre adeptos da prática (vaquejada) e os defensores da proteção aos animais. Mencionou-se, inclusive, uma Frente Parlamentar em Defesa da Vaquejada. A emenda buscava fixar uma permissão constitucional para a prática. Poder-se-ia fixar a vaquejada como patrimônio cultural brasileiro, justificando-se proteção especial do Estado, na medida em que registrada nos livros aos quais se refere o Decreto o 3.551, de 4.8.2000, que instituiu o Registro de Bens Culturais de Natureza Imaterial, com expectativa de que a vaquejada fosse regulamentada, garantindo-se a integridade física e material dos animais. Com isso, seria propósito da emenda atender à orientação do STF. É o que se lê na justificativa da proposta de alteração da Constituição.

A Emenda ำ 96, de 2017, não atende a outros problemas que rondam o assunto, a exemplo dos sacrifícios religiosos. Levantam-se dúvidas sobre sua aplicabilidade, quando confrontada com o decidido pelo STF em ações similares, inclusive no caso da própria vaquejada.

Uma das funções do processo civilizatório, do qual o direito é um agente, consiste na formulação de arranjos e de medidas corretivas que mitiguem o sofrimento, a dor, a humilhação dos seres viventes. Nessa linha, as decisões do STF sufragam um avanço, ainda que temperadas (necessariamente) pela variável decorrente do enfrentamento do preconceito e do estigma, como ocorreu no julgamento dos sacrifícios para fins religiosos. Por outro lado, intrigante a formulação legislativa que efetivamente não levou em conta posição fechada pelo Poder Judiciário.

A Emenda ํo 96, de 2017, ao que parece, teria deixado de seguir orientação do Supremo Tribunal Federal. Em face da mencionada emenda o Fórum Nacional de Proteção e Defesa Animal ajuizou ação direta de inconstitucionalidade ${ }^{23}$ logo estendida a vários amici curiae. A ADI foi ajuizada em 13.6.2017, isto é, sete dias após a promulgação da emenda.

Invocou-se que o Congresso não poderia ter aprovado mencionada emenda, na qualidade de poder moderador, na medida em que teria desrespeitado cláusula pétrea: a Constituição veda emenda que contenha tendência a abolir os direitos e garantias individuais. ${ }^{24}$ Estaria ameaçado o meio ambiente equilibrado, no sentido em que o meio ambiente sadio se revela como uma garantia do indivíduo. Acrescentou-se que o STF havia fulminado a vaquejada, em todos os aspectos, inclusive como uma manifestação cultural. Os requerentes também argumentam

23 STF. ADI no 5.728. Rel. Min. Dias Toffoli.

24 Constituição Federal, art. 60, §4ํㅜ, IV. 
que a emenda suscita o retrocesso, o que vedado, no contexto da construção conceitual que veda o retrocesso.

O Ministério Público Federal opinou pelo procedimento da ação e, consequentemente, pela inconstitucionalidade da emenda constitucional que rejeitou a decisão do STF. ${ }^{25} \mathrm{O}$ centro da argumentação do MPF consiste na constatação de que há limitações materiais ao poder constituinte reformador. Não haveria, nesse caso, por parte do Congresso, autorização constitucional para deixar de levar em conta disposições de cláusulas pétreas. No entender do MPF a emenda constitucional questionada violava regra constitucional que impõe ao Poder Público a proteção da fauna e da flora, bem como veda as práticas que possam submeter os animais a qualquer forma de crueldade. Assim, persiste dúvida quanto à constitucionalidade de emenda que teria enfrentado decisão do STF no minado campo de colisão entre dois dispositivos constitucionais.

\section{Considerações finais}

Um ponto comum no conjunto das decisões apresentadas é identificado a partir de enfrentamento de inegável antinomia do texto constitucional que parece opor direitos culturais ao direito ambiental em sentido amplo e direitos culturais que são opostos à vedação da crueldade para com os animais em sentido estrito. Nas antinomias clássicas, que ocorriam no campo da legalidade em geral, critérios de antiguidade, de especialidade e de hierarquia eram suficientes para a resolução dos conflitos que havia. Em âmbito estritamente constitucional, o choque é um problema axiológico. Por isso, opções valorativas substancializam as várias decisões.

Os julgados do STF aqui apresentados ofereceram miríade de argumentos que muitas vezes alcançam resultados idênticos, ainda que por caminhos aparentemente distintos. A invocação que Ayres Britto fez do preâmbulo como justificativo da proibição da rinha de galos, porque o preâmbulo foi cogitado e redigido em nome de Deus, é dessa afirmação um exemplo eloquente. A analogia de Luiz Fux, quanto ao consentimento humano nos esportes de confronto em face da representação estatal em favor dos bovinos também oferece capcioso exemplo de criatividade hermenêutica.

Nos julgados mencionados não escapam argumentos utilitaristas de ordem econômica, a exemplo da força de trabalho empregada direta e indiretamente na

25 Ministério Público Federal, Parecer, no 50-SDHDC/GABPGR, subscrito pela Procuradora-Geral da República Raquel Elias Ferreira Dodge. 
vaquejada. Manifestações culturais implicam ações de resultado material; podese falar, inclusive, em turismo de interesse religioso. 0 setor empresarial ligado à vaquejada, à farra do boi e os apostadores individuais que se interessam pela briga de galo se ressentem de decisões judiciais que frustram programações, em nome da defesa da vedação da crueldade para com os animais. No caso da vaquejada, os autores do projeto de emenda constitucional que a permitiria falavam em torno de 700 mil empregos que estariam em risco.

Outro aspecto que suscita reflexão decorre do fato de que não pode se isolar a livre prática da religião das manifestações culturais. A religião é manifestação cultural, em todos seus aspectos. A religião é manifestação cultural identificadora da condição humana. A negativa da pretensão dos adeptos das religiões de matriz africana, referente à possibilidade do sacrifício com animais, problematizaria ainda mais as relações entre Estado e Religião, historicamente marcadas por contradições e paradoxos (CHEHOUD, 2013). A referência ao transcendente, ao sobrenatural e ao absoluto é recorrente na experiência cultural (MACHADO, 1996), que informa a construção das normas jurídicas em geral.

Regra de limitação a essa construção cultural que se oponha a esse direito humano fundamental - liberdade de crença - exige inegável fundamentação em parâmetros de racionalidade, proporcionalidade e razoabilidade (BERNAL PULIDO, 2005). Ainda que, bem entendido, o núcleo da racionalidade possa não se comunicar transitivamente com preocupações de ordem metafísica.

A defesa intransigente dos direitos dos animais, especialmente como percebida em pensadores como Peter Singer e Tom Regan (ZIMMERMANN et al., 1993), em oposição em referenciais estruturantes de liberdade religiosa, sugere conjunto de restrições, cuja solução demanda recursos retóricos de reservas gerais de ponderação (RAMOS, 2017).

No caso dos sacrificios com animais para efeitos religiosos, a um imaginário Estado Socioambiental de Direito (SARLET; FENSTERSEIFER, 2014) opõese resposta estatal de prestígio a comunidades historicamente estigmatizadas e violentadas por uma lógica de exclusão. A superação da dogmática tradicional em matéria constitucional (BARROSO, 2009) demanda uma agenda para tomada de decisões que revele cautelosas técnicas de exercício de proporcionalidade (BERNAL PULIDO, 2007). Direitos fundamentais, quando cotejados com restrições de ordem de igual modo constitucionais, também exigem fundamentação (ALEXY, 2007).

A esse problema de ordem constitucional, que opõe valores, tradições e manifestações religiosas e culturais, há também um problema afeto à teoria geral do direito, e mais especificadamente à dogmática do direito constitucional, referente à possibilidade (ou não) de o Congresso aprovar emenda que contrarie 
decisão do STF. O conflito transcende a letra e a interpretação da Constituição, alcançando, na essência, o dogma da independência e harmonia entre os poderes.

\title{
Brazilian Constitutional Amendment 96/2017 and the subject of the cruelty against animals in the Brazilian Supreme Court framework of culture and religion
}

\begin{abstract}
The paper tackles the conflict between the content of a recent Brazilian Constitutional amendment in the face of an opinion delivered by the Brazilian Supreme Court. With this aim, the paper signposts and clarifies the general lines of several Court discussions in which were at stake values related to the Brazilian cultural patrimony, event in its religious framework, as opposed to constitutional rule regarding the prevention of the cruelty towards the animals.
\end{abstract}

Keywords: Constitutional Amendment and the ruling of the Brazilian Supreme Court. Conflicts among Constitutional provisions. The safeguard of the cultural patrimony. Religious liberty. Cruelty towards the animals. Proscriptions.

Contents: Preliminary remarks and the scope of the question - "Farra do boi" case - "Cock fighting" "Vaquejada" and the sacrifice of animals for religious purposes - Constitutional Amendment 96/2017

- Final remarks - References

\section{Referências}

ADRAGÃO, Paulo Pulido. Liberdade religiosa e o Estado. Coimbra: Almedina, 2002.

BACHOF, Otto. Normas constitucionais inconstitucionais. Tradução de José Manuel M. Cardoso da Costa. Coimbra: Almedina, 1994.

BARROSO, Luís Roberto. Interpretação e aplicação da Constituição. São Paulo: Saraiva, 2009.

BERNAL PULIDO, Carlos. El derecho de los derechos. Bogotá: Universidad de Externado de Colomgia, 2005.

BERNAL PULIDO, Carlos. El principio de proporcionalidad y los derechos fundamentales. Madrid: Centro de Estudios Constitucionales, 2007.

BICKEL, Alexander M. The last dangerous branch - The Supreme Court and the Bar of Politics. New Haven and London: Yale University Press, 1986.

CHEHOUD, Helóisa Sanches. A liberdade religiosa nos estados modernos. São Paulo: Almedina, 2012.

DUARTE, Maria Luísa; GOMES, Carla Amado. Animais: deveres e direitos. Lisboa: ICJP, 2015.

GARZÓN VALDÉS, Ernesto; ALEXY, Robert. Teoría del discurso y derechos constitucionales. Ciudad del Mexico: Fontamara, 2007.

GOMES, Carla Amado (Coord.); DICKSTEIN, André; GIORDANO, Nathalie; GONÇALVES, Monique Mosca (Org.). Anotações de jurisprudência ambiental brasileira. Lisboa: ICJP/CIDP, 2020.

HIRSCHL, Ran. Towards juristocracy - The origins and consequences of the new constitutionalism. Cambridge: Harvard University Press, 2007.

LEAL, Roger Stiefelmann, O efeito vinculante na jurisdição constitucional. São Paulo: Saraiva, 2006.

LEFF, Enrique. Epistemologia ambiental. Tradução de Sandra Valenzuela. São Paulo: Cortez, 2002. 
LEITE, George Salomão; SARLET, Ingo Wolfgang. Direitos constitucionais e Estado Constitucional Estudos em homenagem a J. J. Gomes Canotilho. São Paulo: Revista dos Tribunais; Coimbra: Coimbra Editora, 2009.

MACHADO, Jónatas Eduardo Mendes. Liberdade religiosa numa comunidade constitucional inclusiva Dos direitos da verdade aos direitos do cidadão. Coimbra: Coimbra Editora, 1996.

MANCUSO, Rodolfo de Camargo. Sistema brasileiro de precedentes. São Paulo: Revista dos Tribunais, 2014.

MARINONI, Luiz Guilherme. A eficácia dos precedentes. São Paulo: Revista dos Tribunais, 2014.

MARINONI, Luiz Guilherme. Precedentes obrigatórios. São Paulo: Revista dos Tribunais, 2016.

MILLER JR., C. Ciência ambiental. Tradução de All Tasks. São Paulo: Thompson Learning, 2007.

RAMOS, André de Carvalho. Curso de direitos humanos. São Paulo: Saraiva, 2017.

ROTHENBURG, Walter Claudius. Direitos fundamentais. São Paulo: Gen e Método, 2014.

SARLET, Ingo Wolfgang. A eficácia dos direitos fundamentais - Uma teoria geral dos direitos fundamentais na perspectiva constitucional. Porto Alegre: Livraria do Advogado, 2015.

SARLET, Ingo Wolfgang; FENSTERSEIFER, Tiago. Princípios de direito ambiental. São Paulo: Saraiva, 2014.

SARMENTO, Daniel. Dignidade da pessoa humana - Conteúdo, trajetórias e metodologia. Belo Horizonte: Fórum, 2016.

SCRUTON, Roger. Filosofia verde - Como pensar seriamente o planeta. Tradução de Maurício G. Righi. São Paulo: Realizações, 2016.

SINGER, Peter. Ética prática. Tradução de Jefferson Luiz Camargo. São Paulo: Martins Fontes, 2002.

VALE, André Rufino do. Estrutura das normas de direitos fundamentais - Repensando a distinção entre regras, princípios e valores. São Paulo: Saraiva, 2009.

VERGÉS RAMíREZ, Salvador. Derechos humanos: fundamentación. Madrid: Tecnos, 1997.

WALDRON, Jeremy. Law and disagreement. Oxford: Oxford University Press, 2004.

WEINGARTNER NETO, Jayme. Liberdade religiosa na Constituição. Porto Alegre: Livraria do Advogado, 2007.

ZIMMERMAN, Michael E. et al. Environmental philosophy - From animals rights to radical ecology. New Jersey: Prentice Hall, 1993.

Informação bibliográfica deste texto, conforme a NBR 6023:2018 da Associação Brasileira de Normas Técnicas (ABNT):

GODOY, Arnaldo Sampaio de Moraes. A Emenda Constitucional ํo 96, de 6.6.2017 e o tema da crueldade contra os animais no contexto da cultura e da religião na construção jurisprudencial do Supremo Tribunal Federal. Direitos Fundamentais \& Justiça, Belo Horizonte, ano 14, n. 42, p. 485-506, jan./jun. 2020.

Recebido em: 22.07.2019

Pareceres: 10.04.2020, 22.04.2020

Aprovado em: 27.04.2020 